\title{
CHARACTERIZATION OF NON-FERROUS METAL POWDERS
}

\section{KARAKTERIZACIJA NEŽELEZNIH KOVINSKIH PRAHOV}

\author{
Jakob Kraner $^{1 *}$, Jožef Medved ${ }^{2}$, Matjaž Godec ${ }^{1}$, Irena Paulin ${ }^{1}$ \\ ${ }^{1}$ Institute of Metals and Technology, Lepi pot 11, 1000 Ljubljana, Slovenia \\ ${ }^{2}$ Faculty of Natural Sciences and Engineering, Department of Materials and Metallurgy, Aškerčeva cesta 12, 1000 Ljubljana, Slovenia
}

Prejem rokopisa - received: 2019-09-06; sprejem za objavo - accepted for publication: 2019-11-04

doi: $10.17222 / \mathrm{mit} .2019 .213$

With the extended use of additive manufacturing in the past few years, powder metallurgy is quickly acquiring a more important role in world industry. Because the metal powder represents the initial material for most of additive-manufacturing processes, the properties of final products are directly influenced by the powder properties. Besides the product properties, the chosen process parameters are based on the characteristics of the powder. In this work the physical and thermal properties as well as the microstructure of different non-ferrous metal powders were investigated. The flow rate, tap and apparent density, angle of repose, compression factor and Hauser ratio were measured or calculated. The microstructures of separate metal powder particles were observed with a light microscope. The particles' shape, size and roughness were investigated with a scanning electron microscope and the correlations with the determined physical properties were found. From the heating and cooling cycle curves of different scanning calorimetries the liquid and solidification temperatures were determined and the influence of the chemical composition on them was observed.

Keywords: powder metallurgy, powder properties, different scanning calorimetry, microstructure

Z obsežnejšo uporabo dodajalnih tehnologij v zadnjih nekaj letih je tudi metalurgija prahov dobila precej bolj pomembno vlogo v svetovni industriji. Za postopke dodajalnih tehnologij kovinski prah predstavlja vhodni material, kar pomeni, da so lastnosti izdelkov narejenih z dodajalno tehnologijo, neposredno odvisne od lastnosti prahu. Hkrati so od lastnosti prahu odvisni tudi izbrani parametri procesa. Študija je zajemala raziskave fizikalnih in termičnih lastnosti, kot tudi opazovanje mikrostrukture različnih neželeznih kovinskih prahov. Določene ali izračunane so bile tekočnost, nasipna in stresalna gostota, nasipni kot, faktor stisljivosti in Hauserjevo razmerje. Mikrostruktura posameznih prašnih delcev je bila opazovana s svetlobnim mikroskopom. Oblika, velikost in hrapavost prašnih delcev so bili preiskovani z vrstičnim elektronskim mikroskopom. Opažene so bile določene povezave med karakteristikami prašnih delcev in izmerjenimi lastnostmi prahu. S segrevalnimi in ohlajevalnimi krivuljami diferenčne vrstične kalorimetrije so bile določene temperature pričetka taljenja in strjevanja. Opazovan je bil tudi vpliv kemijske sestave na spreminjanje omenjenih temperatur.

Ključne besede: metalurgija prahov, lastnosti prahu, diferenčna vrstična kalorimetrija, mikrostruktura

\section{INTRODUCTION}

Non-ferrous metal powder applications cover a lot of different production areas. ${ }^{1,2}$ The most extensive use is for now in the aerospace and automotive industries, the metal powders are used for the production of jet engines, heat shields, valve inserts, bushings and gears. ${ }^{3} \mathrm{Al}$ powders were especially used for the metallurgical purpose of recovery and alloying, in the office equipment with electrostatic copiers and cams. ${ }^{4} \mathrm{Cu}$ powders are more present in the joining of solders and electrodes, as lubrication greases and abradable seals. ${ }^{5}$ The extensive increase of metal powder production and consumption was caused by additive manufacturing which has had an impact in recent years. ${ }^{6,7}$

For additive manufacturing the spherical shape of the powder particles is recommended, because the flow rate of the powder must be suitable for the smooth layers. ${ }^{8}$ The granulation or better said, for the additive manufacturing, a suitable powder particle size is for $\mathrm{Al}$ powders in the different literature defined differently.

*Corresponding author's e-mail:

jakob.kraner@imt.si (Jakob Kraner)
K. Kempen et al. ${ }^{9}$ used powder with a granulation between $16 \mu \mathrm{m}$ and $48 \mu \mathrm{m}$. The particle size from $45 \mu \mathrm{m}$ to $75 \mu \mathrm{m}$ was recommended by E. O. Olakanmi et al. ${ }^{10}$ E. Brand et al. ${ }^{11}$ reported that the best granulation of $\mathrm{Al}$ powder particle size was between $25 \mu \mathrm{m}$ and $40 \mu \mathrm{m}$. In all the mentioned research a spherical shape of powder was used, but it would be interesting to know if with the irregular shapes of powder particles satisfactory flowability can be reached. The variations in granulation there will be one of the options. To create the powder with the spherical shape gas atomisation with inert gas must be used. ${ }^{12}$ In comparison to the gas atomisation with air and water atomisation the powder production with inert gas is the most expensive. Murry et al. ${ }^{13}$ successfully made the spheroidisation of metal powder by pulsed electron beam irradiation as a post process in metal powder production.

Metal powder represents the basic and input material for the parts produced with additive manufacturing. That way the characterisation of the powder has a key impact for the planning of a material's final properties. ${ }^{14-16}$ Besides the characterisation of the physical properties of the metal powder and its particles, the thermodynamic characterisation is important as well. A. Arockiasamy et 
al. ${ }^{17}$ made a differential scanning calorimetry (DSC) analysis of aluminium alloy powder by rapid solidification, which is a fairly good approximation of the processes in additive manufacturing. At the same time the importance of powder mixing simplicity was highlighted, because the new alloys can be so produced.

In this investigation the chemical composition of different non-ferrous powders was performed with fluorescence spectrometer (XRF) to verify the accuracy of the producers. Furthermore, differential scanning calorimetry (DSC) was used to study the behaviour of the powder among thermal changes. For the observation of the separate powder particle microstructure a light microscope (LM) was used. The particle shape, size and roughness were analysed with a scanning electron microscope (SEM).

\section{MATERIALS AND METHODS}

Characterization was carried out on the six nonferrous powders. All the analysed powders were industrially produced with atomisation and beside the chemical composition, the production method and the production company were different. The chemical composition was, in laboratory, controlled by the XRF Thermo Scientific Niton XL3t GOLDD+. The chemical compositions of the analysed metal powders are presented in Table 1. Among the selected metal powders the three pure aluminium powders with designations $\mathrm{Al}, \mathrm{KR}$ and EX, two powders of aluminium alloy marked with AlSi12 and AlSi10Mg and pure copper powder with $\mathrm{Cu}$ designation were observed. The physical properties were measured three times for each powder so that the repeatability was ensured. For each test a fresh powder was used. The flowability $f$ was measured with a Hall flowmeter, which is in accordance with standard ASTM B213. The angle of repose $A_{\mathrm{R}}$ and the apparent density $\rho_{\mathrm{A}}$ were determined on the same measuring device. Measurements were performed in accordance with the ASTM B212 and ASTM C1444 standards. For determining the tap density $\rho_{\mathrm{T}}$ a measuring device that corresponds to the standard ASTM B527 was used. From the obtained initial volume $V_{\mathrm{I}}$ and end volume $V_{\mathrm{E}}$ with tap density $\rho_{\mathrm{T}}$ measurements the compression factor $C_{\mathrm{f}}$ with Equation (1) and Hauser ratio $H$ with Equation (2) were calculated.

$$
\begin{gathered}
C_{\mathrm{f}}=100 \cdot \frac{\left(V_{\mathrm{I}}-V_{\mathrm{E}}\right)}{V_{\mathrm{I}}} \\
H=\frac{V_{\mathrm{I}}}{V_{\mathrm{E}}}
\end{gathered}
$$

For the shape, size and roughness observation of metal-powder particles the SEM ZEISS FIBSEM CrossBream 550 was used. The powder was poured on self-adhesive tape without further processing. The microstructure was observed with a LM ZEISS Imager.Z2m.
For this purpose the powder was mounted, grinded and polished. Thermodynamic analysis was, for chosen powders, carried out with DSC on NETZSCH STA 449C Jupiter. Ceramic cups and Pt covers were annealed on $800{ }^{\circ} \mathrm{C}$ before the test. The DSC experiments were performed in vacuum. As the reference material, Pt was used. Each DSC measurement was repeated with new powder.

Table 1: Chemical composition of analysed metal powders

\begin{tabular}{|c|c|c|c|c|c|}
\hline Designation & $\begin{array}{c}\mathrm{Al} \\
(w / \%)\end{array}$ & $\begin{array}{c}\mathrm{Si} \\
(w / \%)\end{array}$ & $\begin{array}{c}\mathrm{Mg} \\
(w / \%)\end{array}$ & $\begin{array}{c}\mathrm{Fe} \\
(w / \%)\end{array}$ & $\begin{array}{c}\mathrm{Cu} \\
(w / \%)\end{array}$ \\
\hline $\mathrm{Al}$ & 99.5 & - & - & 0.3 & - \\
\hline $\mathrm{KR}$ & 99.5 & - & - & 0.2 & - \\
\hline $0 \mathrm{EX}$ & 99.4 & - & - & 0.3 & - \\
\hline $\mathrm{AlSi} 12$ & 88.5 & 11.0 & - & 0.3 & - \\
\hline $\mathrm{AlSi} 10 \mathrm{Mg}$ & 88.7 & 10.6 & 0.3 & 0.2 & - \\
\hline $\mathrm{Cu}$ & - & - & - & - & 99.5 \\
\hline
\end{tabular}

\section{RESULTS AND DISCUSSION}

\subsection{Physical properties}

The highest flowability of $3.11 \mathrm{~g} / \mathrm{s}$ was measured for the $\mathrm{Cu}$ powder. The much higher flow rate than the aluminium powders can be a consequence of the higher density, which is also confirmed by the apparent and tap densities of the $\mathrm{Cu}$ powder. Between all the aluminium powders the AlSi10Mg has the highest flowability. For the powder $\mathrm{Al}$ and AlSi12, the flow rate determination was unfeasible. The reason is usually the too small granulation of powder. The angles of repose are for all 6 analysed powders between $45^{\circ}$ and $60^{\circ}$. The correlation between the flow rate and the angle of repose can be observed in the way that the higher angles appear with $\mathrm{Al}$ and AlSi12 where the flowability was not possible to determine and the lowest angle of repose was measured for the $\mathrm{Cu}$ powder with a high flow rate. The tap density for all the analysed powders was lower than the apparent density, which is completely normal. The apparent and tap densities are for aluminium powders between $1.20 \mathrm{~g} / \mathrm{cm}^{3}$ and $1.51 \mathrm{~g} / \mathrm{cm}^{3}$. The compression factor is also in relation with the flowability and the angle of repose. The highest compression factor of 13.00 was calculated for the powder AlSi12. A similar high compression factor of 9.67 was also calculated for the $\mathrm{Al}$

Table 2: Physical properties of analysed metal powders

\begin{tabular}{|c|c|c|c|c|c|c|}
\hline $\begin{array}{c}\text { Desig- } \\
\text { nation }\end{array}$ & $\begin{array}{c}\text { Flow- } \\
\text { ability } \\
(\mathrm{g} / \mathrm{s})\end{array}$ & $\begin{array}{c}\text { Angle } \\
\text { of } \\
\text { repose } \\
\left({ }^{\circ}\right)\end{array}$ & $\begin{array}{c}\text { Appar- } \\
\text { ent } \\
\text { density } \\
\left(\mathrm{g} / \mathrm{cm}^{3}\right)\end{array}$ & $\begin{array}{c}\text { Tap } \\
\text { density } \\
\left(\mathrm{g} / \mathrm{cm}^{3}\right)\end{array}$ & $\begin{array}{c}\text { Com- } \\
\text { pression } \\
\text { factor } \\
(/)\end{array}$ & $\begin{array}{c}\text { Hauser } \\
\text { ratio } \\
(/)\end{array}$ \\
\hline $\mathrm{Al}$ & - & 60 & 1.31 & 1.51 & 9.67 & 1.11 \\
\hline $\mathrm{KR}$ & 0.64 & 45 & 1.20 & 1.30 & 4.67 & 1.05 \\
\hline $\mathrm{EX}$ & 0.67 & 47 & 1.23 & 1.33 & 5.67 & 1.06 \\
\hline $\mathrm{AlSi} 12$ & - & 57 & 1.27 & 1.51 & 13.00 & 1.15 \\
\hline $\mathrm{AlSi} 10 \mathrm{Mg}$ & 0.95 & 45 & 1.40 & 1.50 & 6.00 & 1.06 \\
\hline $\mathrm{Cu}$ & 3.11 & 36 & 4.44 & 4.71 & 3.33 & 1.03 \\
\hline
\end{tabular}



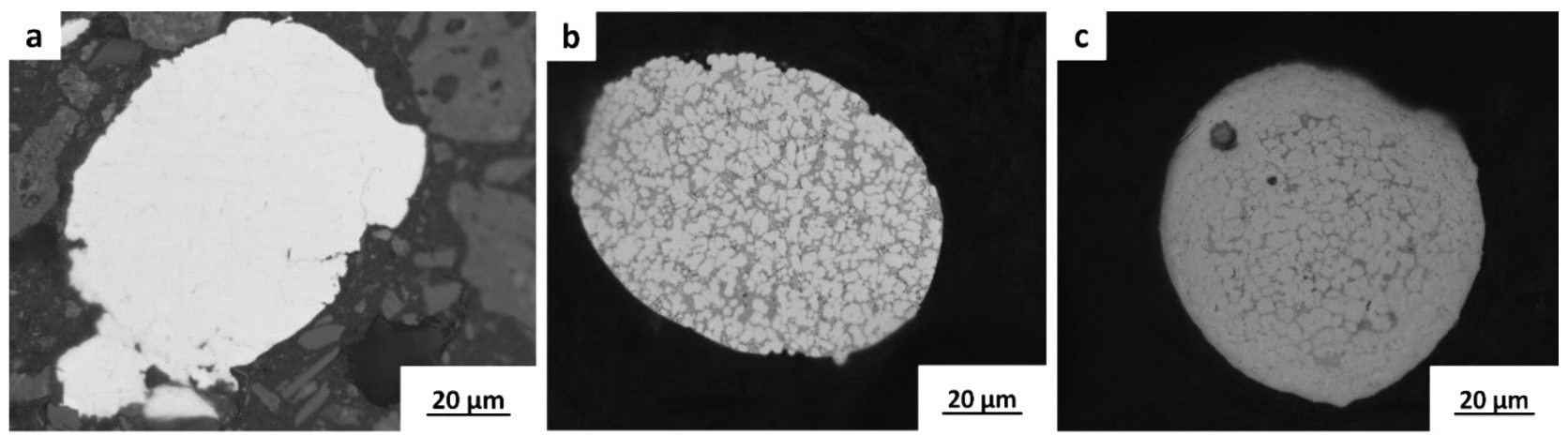

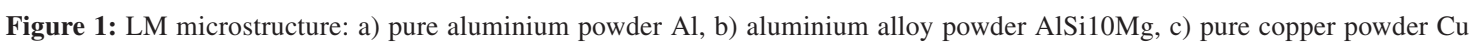

powder. The lowest compression factor of 3.33 was calculated for the $\mathrm{Cu}$ powder. The higher compression factor of the powders should provide a more successful sintering. On the other hand, the higher flowability of the metal powder will be more desirable for additive manufacturing processes. ${ }^{18}$ The Hauser ratios for all six analysed powders were between 1.03 and 1.15 . The measured and calculated physical properties of the metal powders are in Table 2.

\subsection{Microstructure}

With the LM the microstructure of separate powder particles was observed. For the Al, KR and EX powders only the primary crystal grains of $\alpha_{\mathrm{Al}}$ were obtained (Figure 1a). It confirms the purity of technically clean aluminium powders. In Figure 1b the microstructure of the AlSi10Mg powder is presented. The dendrites of $\alpha_{\mathrm{Al}}$ and eutectic $\alpha_{\mathrm{Al}}+\beta_{\mathrm{Si}}$ were observed. The microstructure of the AlSi12 powder is very similar to the presented microstructure. Figure 1c presents the microstructure of the $\mathrm{Cu}$ powder. The primary $\alpha_{\mathrm{Cu}}$ was observed as well as some intermediate phases between them. Because no other metal element was detected with XRF, the intermediate phases can be oxides or sulphides. In any case, the presence of one or the other reduces the purity of the $\mathrm{Cu}$ powder. $\mathrm{M}$. Godec et al. ${ }^{19,20}$ emphasized the thickness and the chemistry of the surface oxide film. A very important characteristic in powder metallurgy, partially lose the effects in additive manufacturing, because the input energy often also melts the oxides. Unfortunately, problems with impurities and melt effects remain.

\subsection{Shape and size}

The SEM was used to determine the shape and size and to observe the roughness of the powder particles. Spherical powder particles were observed in the AlSi10Mg and $\mathrm{Cu}$ powders (Figure 2a). For the production of these two powders gas atomisation with an inert gas was used. The spherical shape of powder particles increases the flowability of the powder. Powders with high flowability are more suitable for use in additive manufacturing. ${ }^{14}$ With all the other analysed powders the irregular and rounded shape of the powder particles was observed (Figure 2b).

Like the shape of metal powder particles also the particle's size has an influence on the flowability. The smallest particles, around $20 \mu \mathrm{m}$ or $25 \mu \mathrm{m}$, were measured with the $\mathrm{Al}$ and AlSi12 powders. At the same time both mentioned powder particles were measured to be $340 \mu \mathrm{m}$, which is a very large range of granulation and has negative influence on the flowability. Other
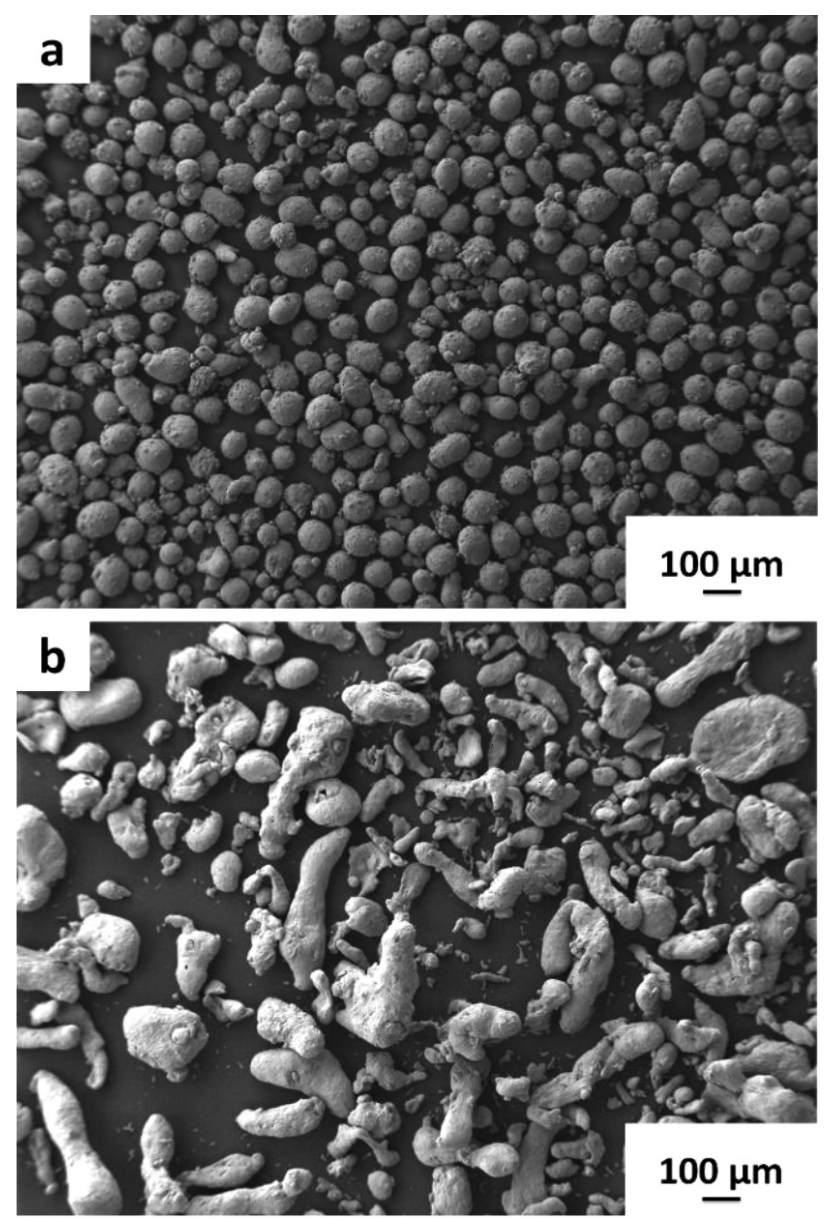

Figure 2: SEM images of powders: a) spherical shape of AlSi10Mg, b) irregular and rounded shape of $\mathrm{Al}$ 
powders had a significantly smaller granulation range. On the surface of the technically pure powders the shapes of the crystal grains were observed. It gives the impression of a rougher surface of the powder particles, as compared to the alloyed powders.

\subsection{Differential scanning calorimetry}

The heating cycle of the DSC curves for the analysed powders were presented in Figure 3a. In Figure 3b the cooling cycles of the DSC curves are shown. The heating curves for pure aluminium powders $\mathrm{Al}, \mathrm{KR}$ and $\mathrm{EX}$ are very similar. The liquid temperatures $\left(T_{1}\right)$ are for the mentioned powders $645.6{ }^{\circ} \mathrm{C}$ for $\mathrm{Al}, 646.2{ }^{\circ} \mathrm{C}$ for $\mathrm{KR}$ and $645.9{ }^{\circ} \mathrm{C}$ for EX. This less than $1{ }^{\circ} \mathrm{C}$ difference between all three powders, confirmed the similar chemical composition. The presence of 0.2 or $0.3 w / \% \mathrm{Fe}$ in the chemical composition reduced the $T_{1}$ by almost $15{ }^{\circ} \mathrm{C}$ in comparison to the pure aluminium with $T_{1} 660.3{ }^{\circ} \mathrm{C}$. Even smaller differences were observed for technically pure aluminium powders $\mathrm{Al}, \mathrm{KR}$ and $\mathrm{EX}$ in beginning solidification-temperature $T_{\mathrm{s}}$. The $T_{\mathrm{s}}$ values for the presented powders are between $652.2^{\circ} \mathrm{C}$ and $653.0{ }^{\circ} \mathrm{C}$. The $T_{1}$ of aluminium alloy powder AlSi12 is $570.4{ }^{\circ} \mathrm{C}$,
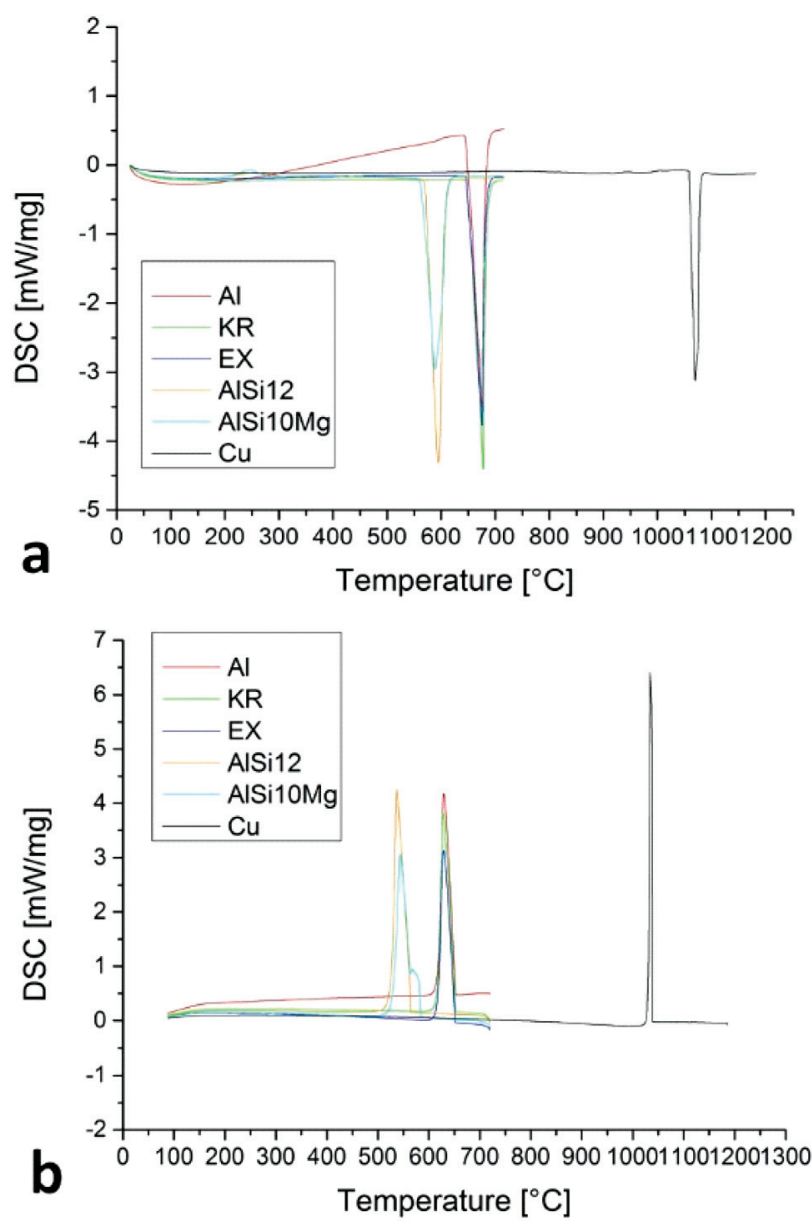

Figure 3: DSC curves for the analysed powders: a) heating cycle, b) cooling cycle which is much lower than the pure aluminium powders. The somewhat lower $T_{1}$ was observed with the aluminium alloy powder AlSi10Mg. The $T_{1}$ for AlSi10Mg is $560.3{ }^{\circ} \mathrm{C}$. For $T_{\mathrm{s}}$ of AlSi12 and AlSi10Mg the vice versa situation has appeared. The $T_{\mathrm{s}}$ for AlSi12 is $564.3{ }^{\circ} \mathrm{C}$ is around $20{ }^{\circ} \mathrm{C}$ lower than the $T_{\mathrm{s}}$ for AlSi10Mg, which is $584.4{ }^{\circ} \mathrm{C}$. The above stated is expressed as a much larger interval of primary solidification of $\alpha_{\mathrm{Al}}$ with AlSi10Mg as with the AlSi12 powder. The $\mathrm{Cu}$ powder's $T_{1}$ was noted to be $1058.5^{\circ} \mathrm{C}$. In comparison to the pure copper with $1084.5{ }^{\circ} \mathrm{C} T_{1}$, the lower $T_{1}$ can be explained with the presence of oxides or sulphides, which have been observed in the microstructure. The $T_{\mathrm{s}}$ is $1038.6{ }^{\circ} \mathrm{C}$ for the $\mathrm{Cu}$ powder.

In comparison to the analysed pure aluminium powders and aluminium alloy powders the $\mathrm{Cu}$ powder has a much smaller interval of melting and solidification.

\section{CONCLUSIONS}

Six non-ferrous metal powders were analysed. Regarding the chemical composition, the selection of powders covered three technically pure aluminium powders with $\mathrm{Fe}$ additions of 0.2 w/\% or 0.3 w/\% from different manufacturers, two aluminium alloy powders AlSil2 and AlSilOMg and a pure copper powder. The spherical shape of the powder particles with granulation of less than $120 \mu \mathrm{m}$ between the smallest and largest measured particle was obtained with the copper and the AlSi10Mg powder. The mentioned powders were produced with gas atomisation with inert gas, specifically for the additive manufacturing. The smaller difference in granulation and especially the spherical shape of powder particles has a positive influence on the increase of the powder flowability, which has a key impact on the additive manufacturing processes. With all the other analysed powders the irregular and rounded shapes of particles were observed. The stated particle shapes as well as the larger granulation differences reduced the powder flowability. Due to the too small granulation of the powder particles, the flow rate with the Hall flowmeter could not be measured for two of the powders. These two powders had a very high compression factor, which is a good indicator for a successful sintering. Because much thicker oxide layers form on the surface of the powder particles made with water atomisation, the gas atomisation with air was used to produce the other four powders. With the differential scanning calorimetry a much lower liquid temperature of aluminium alloy powders compared to the pure aluminium powders was confirmed. Due to different additions to aluminium alloy powders, a larger number of different phases arose, which was detected in the form of numerous changes to the cooling cycle curves. This can cause problems with breaking segregation of the separate hardening phases in additive manufacturing processes, where the working temperatures are higher and the cooling time intervals 
are smaller than reached with the differential scanning calorimetry tests.

An exciting example was the pure copper powder, where much higher melting and solidification temperatures were needed. In comparison, the width of the melting and solidification intervals for pure aluminium powders and aluminium alloy powders were very similar. At the same time, the mentioned intervals are much smaller for the pure copper powder.

\section{Acknowledgements}

The authors acknowledge the financial support from the Slovenian Research Agency, research core funding No. P2-0132 in J2-1729.

\section{REFERENCES}

${ }^{1}$ B. Šuštaršič, J. Medved, S. Glodež, M. Šori, A. Korošec, DSC/TG of Al-based alloyed powders for P/M applications, Mater. Tehnol., 48 (2014), 531-536

${ }^{2}$ B. Šuštaršič, I. Paulin, M. Godec, S. Glodež, M. Šori, J. Flašker, A. Korošec, S. Kores, G. Abramović, Morphological and microstructural features of Al-based alloyed powders for powder-metallurgy applications, Mater. Tehnol., 48 (2014), 439-450

${ }^{3}$ S. Ford, M. Despeisse, Additive manufacturing and sustainability: an exploratory study of the advantages and challenges, J. Clean. Produc., 137 (2016), 1573-1587, doi:10.13140/RG.2.1.3284.3601

${ }^{4}$ G. A. Sweet, R. I. Hexemer Jr., I. W. Donaldson, A. Taylor, D. P. Bishop, Powder metallurgical processing of a $2 \mathrm{xxx}$ series aluminum powder metallurgy metal alloy reinforced with AlN particulate additions, Mat. Sci. Eng. A, 755 (2019), 10-17, doi:10.1016/j.msea. 2019.03.122

${ }^{5}$ A. P. Ventura, C. J. Marvel, G. Pawlikowski, M. Bayes, M. Watanabe, R. P. Vinci, W. Z. Misiolek, The effect of aging on the microstructure of selective laser melted $\mathrm{Cu}-\mathrm{Ni}-\mathrm{Si}$, Met. Mat. Trans. A, 48 (2017), 6070-6082, doi:10.1007/s11661-017-4363-8

${ }^{6}$ Y. Al-Meslemi, N. Anwer, L. Mathieu, Environmental performance and key characteristics in additive manufacturing: A literature review, Proc. CIRP, 69 (2018), 148-153, doi:10.1016/j.procir.2017. 11.141

${ }^{7}$ C. Fredriksson, Sustainability of metal powder additive manufacturing, Proc. Manuf., 33 (2019) 139-144, doi:10.1016/j.promfg.2019. 04.018
${ }^{8}$ Q. B. Nguyen, M. L. S. Nai, Z. Zhu, C.-N. Sun, J. Wei, W. Zhou, Characteristics of Inconel powders for powder-bed additive manufacturing, Engineering, 3 (2017), 695-700, doi:10.1016/J.ENG. 2017.05.012

${ }^{9}$ K. Kempen, L. Thijs, E. Yasa, M. Badrossamay, W. Verheecke, J.-P. Kruth, Process optimization and microstructural analysis for selective laser melting of AlSi10Mg, 22nd Solid freeform fabrication; an additive manufacturing conference, (2011), 484-495

${ }^{10}$ E. O. Olakanmi, R. F. Cochrane, K. W. Dalgarno, Densification mechanism and microstructural evolution in selective laser sintering of Al-12Si powders, J. Mat. Proc. Tech., 211 (2011), 113-121, doi:10.1016/j.jmatprotec.2010.09.003

${ }^{11}$ E. Brandl, U. Heckenberger, V. Holzinger, D. Buchbinder, Additive manufactured AlSi10Mg samples using selective laser melting (SLM): microstructure, high cycle fatigue, and fracture behaviour, Mat. Des., 34 (2012), 159-169, doi:10.1016/j.matdes.2011.07.067

${ }^{12}$ F. Maggi, S. Dossi, C. Paravan, L. T. De Luca, M. Liljedahl, Activated aluminium powders for space propulsion, Pow. Tech., 270 (2015), 46-52, doi:10.1016/j.powtec.2014.09.048

${ }^{13}$ J. W. Murray, M. Simonelli, A. Speidel, D. M. Grant, A. T. Clare, Spheroidisation of metal powder by pulse electron beam irradiation, Pow. Tech., 350 (2019), 100-106, doi:10.1016/j.powtec.2019.03.041

${ }^{14}$ B. Šuštaršič, L. Kosec, T. Špan, M. Jelenko, M. Torkar, An instrumented cell to analyse the behaviour of metal powders during cold uniaxial die compaction, Mater. Tehnol., 35 (2001), 351-360

${ }^{15}$ B. Šuštaršič, M. Godec, M. Jenko, T. Drglin, S. Dolinšek, Bulk and surface characterisation of metal powders for direct laser sintering, Vacuum, 80 (2005), 29-34 doi:10.1016/j.vacuum.2005.07.019

${ }^{16}$ B. Šuštaršič, S. Dolinšek, M. Jenko, V. Leskovšek, Microstructure and mechanical characteristics of DMLS tool-insert. Mater. Manuf. Proc., 24, (2009), 837-841 doi:10.1080/10426910902841837

${ }^{17}$ A. Arockiasamy, R. M. German, P. Wang, M. F. Horstemeyer, P. Suri, S. J. Park, DSC analysis of Al6061 aluminium alloy powder by rapid solidification, J. Therm. Anal. Calorim., 100 (2010), 361-366, doi:10.1007/s10973-009-0587-1

${ }^{18}$ X. Guiling, L. Ping, L. Menghui, L. Cai, X. Pan, L. Daoyin, C. Xiaoping, Investigation on characterization of powder flowability using different testing methods, Exp. Therm. Flu. Sci., 92 (2018), 390-401, doi:10.1016/j.exptherm?usci.2017.11.008

${ }^{19}$ M. Godec, D. Mandrino, M. Remškar, M. Jenko, B. Šuštaršič, Multi-technique investigations of soft magnetic powders, Mater. Tehnol., 36 (2002), 349-353

${ }^{20}$ M. Godec, B. Šuštaršič, M. Jenko, A high-magnification EBSD mapping analysis of Fe-Si-B powder particles, Metalurgija, 47, (2008), 9-12 